\title{
Ash from Jerusalem artichoke and biopreparations enhance the growth and physiological activity of sorghum and limit environmental pollution by decreasing artificial fertilization needs**
}

\author{
Zdzisława Romanowska-Duda (iib*, Mieczystaw Grzesik ${ }^{2}$, and Regina Janas ${ }^{2}$ iif \\ ${ }^{1}$ University of Łódź, Department of Plant Ecophysiology, Banacha 12/16, 90-237 Łódź, Poland \\ ${ }^{2}$ Department of the Variety Studies, Nursery and Gene Resources, Research Institute of Horticulture, \\ Konstytucji 3 Maja 1/3, 96-100 Skierniewice, Poland
}

Received April 21, 2020; accepted July 29, 2020

\begin{abstract}
An increase in plant productivity and the limitation of environmental pollution through the use of natural fertilizers are becoming the most important issues in contemporary sustainable agriculture. Therefore, the purpose of the research was to demonstrate the effect of Jerusalem artichoke ash, used alone or together with biopreparations and biogas plant waste, on the growth and physiological activity of sorghum and to show their applicability as an alternative to chemical fertilization. The sorghum plants, cultivated in Central and North Poland, were fertilized with the YaraMila Complex, a chemical fertilizer $(0,150$, $300 \mathrm{~kg} \mathrm{ha}^{-1}$ ) and each concentration was supplemented with Jerusalem artichoke ash (0-4 $\left.\mathrm{t} \mathrm{ha}^{-1}\right)$, applied separately or together with Apol-Humus $\left(10 \mathrm{~L} \mathrm{ha}^{-1}\right)$, biogas plant waste $\left(30 \mathrm{~m}^{3} \mathrm{ha}^{-1}\right)$ and Stymjod $\left(5 \mathrm{~L} \mathrm{ha}^{-1}\right)$. Within each YaraMila Complex addition, the all ash doses (preferably 2-4 $\mathrm{t} \mathrm{ha}^{-1}$ ), biopreparations and biogas plant waste significantly enhanced plant growth, biomass yield, chlorophyll content, gas exchange (net photosynthesis, transpiration, stomatal conductance, intercellular $\mathrm{CO}_{2}$ concentration), enzyme activity (acid and alkaline phosphorylase, RNase, dehydrogenase) and slightly enhanced the content of the measured elements in plants and their energy properties. The ash applied together with a lower than recommended amount of YaraMila Complex $\left(0\right.$ or $\left.150 \mathrm{~kg} \mathrm{ha}^{-1}\right)$ increased plant development slightly more than twice the dose of YaraMila Complex used alone (150 or $300 \mathrm{~kg} \mathrm{ha}^{-1}$, respectively). This demonstrates that the studied ash can serve as a natural fertilizer and may halve the recommended chemical fertilizer doses.

Keywords: fertilization, physiological activity, Jerusalem artichoke ash, sorghum growth
\end{abstract}

*Corresponding author e-mail: zdzislawa.romanowska@biol.uni.lodz.pl

**This work was supported by the National Centre for Research and Development, Grant No. BIOSTRATEG2/296369/5/NCBR/ 2016.

\section{INTRODUCTION}

One of the most important necessities in the contemporary economy is to reduce greenhouse gas emissions through the use of biomass as a raw material for obtaining energy instead of fossil fuels. Another goal is to lower soil contamination by decreasing synthetic fertilization through the use of natural fertilizers that do not pollute the environment. These requirements are driving the development of new plant cultivation technologies which allow for the attainment of the maximum yield of biomass convertible to energy and decrease environmental contamination (Faaij, 2006; Biofuels in the EU, 2006; Biofuels Progress Report, 2007; Fernando et al., 2018).

It is assumed that the limitation of the contamination of the agrological environment, caused by the use of excessive doses of synthetic fertilizers and pesticides, can be reduced through plant fertilization with ash from the burnt biomass of plant species containing no toxic substances. Due to the fact that this ash may contain the majority of elements necessary for plant growth and is environmentally benign, its use in agriculture as a fertilizer may be beneficial. Moreover, such an application of ash could solve the problem of its storage, which is dangerous for the environment (Romanowska-Duda et al., 2019b). The use of biomass ash in agriculture as an organic fertilizer and an alternative to chemical soil enrichment may be very advantageous in global plant production from an economic

(C) 2020 Institute of Agrophysics, Polish Academy of Sciences 
and environmental point of view and thus appropriate technologies for its application should be developed. This is particularly important since there are predictions that the amount of biomass converted into electricity will continue to grow, already in 2020 , electricity production from biomass will be higher by $25 \%$, compared to 2010 .

The literature concerning the use of ash from burnt biomass is inadequate and treats this problem in a compartmentalized fashion. In the majority of cases, it concerns the use of ash from burnt wood which originates from forestry. This ash may contain toxic substances absorbed by the trees during their long period of growth (Santalla et al., 2011; Vassiliev et al., 2013). Buss et al. (2019) indicated that the application of wood ash could provide nutrients and increase the $\mathrm{pH}$ of forest soil and it could also temporarily change its chemistry within a relatively short period of time. Jagodzinski et al. (2018) demonstrated the positive effect of ash from burnt wood on Lemna minor L. development, whereas Romanowska-Duda et al. (2019c) showed the stimulating influence of sorghum ash on the development and physiological activity of Lemnaceae. Piekarczyk et al. (2014), Ciesielczuk et al. (2011) and Meller and Bilenda (2012) demonstrated the increased content of nutrients in soil fertilized with ash from burnt plant biomass including barley, wheat and rape. Schiemenz and Eichler-Löbermann (2010) and Schiemenz et al. (2011) have revealed different structures of ash which depend on the plant species burnt, while Park et al. (2005) have shown that the composition of ash from wood was not consistent during three years of research. It is assumed that the use of ash from burnt biomass is more satisfactory than the use of sewage sludge, which may contain not only nutrients important for growth but also toxic substances which must be removed before its use in plant cultivation (Fang et al., 2017; Pszczółkowska et al., 2019).

Because of the inadequate and sometimes inconclusive information concerning this subject, further research is required to explore the influence of ash from particular plant species on different crops under specific soil conditions. Moreover, information concerning the use of plant biomass ash as an alternative to artificial fertilizers, which is the key to decreasing agro environment pollution, is difficult to find in the literature. The possibility of decreasing chemical fertilization through the foliar application of microalgae was demonstrated by Pszczółkowska et al. (2019), Dębowski et al. (2018) and Grzesik et al. (2017a). To the best of our knowledge, a study concerning the use of ash from burnt Jerusalem artichoke in sorghum crops, separately or combined with waste from biogas plant and biopreparations, as well as their impact on plants and soil properties under the conditions of limited artificial fertilization has not been performed to date. Sorghum (Sorghum bicolor L.) variety Rona 1 was selected for the research presented, because this plant is a novel crop with a bright future in Poland and is cultivated for silage and energy production in a changing climate (Krzystek et al., 2018).
The aim of the presented research was to assess the possibility of decreasing artificial fertilization by using ash from burnt Jerusalem artichoke, waste from biogas plants, Apol-Humus and Stymjod. Therefore, the impact of these fertilizers on soil properties and on the development and physiological activity of sorghum under reduced doses of artificial YaraMila Complex was studied.

\section{MATERIAL AND METHODS}

Commercial seeds of sorghum (Sorghum bicolor L.) 'Rona 1' were obtained from a distributor, Kutno Sugar Beet Breeding Company (Poland). The chemical fertilizer YaraMila Complex (Yara), is commercially available in stores with gardening supplies. The ash came from burning fully matured Jerusalem artichoke plants as part of own research. It was sifted on sieves (with $2 \times 2 \mathrm{~mm}$ mesh) before use. Three-year studies showed that the ash prepared in this way was uniform and had a similar effect on plant growth. Thus, from a practical point of view there was no need to divide it into additional factions. Noncentrifuged waste from corn grain biodigestion to methane was obtained from Gamawind Ltd., Piaszczyna, Poland, a distillery integrated with a biogas plant. Apol-Humus, a soil improver, was supplied by the manufacturer Poli-Farm Sp. z o.o., Poland, whereas Stymjod, a nano-organic-mineral fertilizer, was supplied by the producer, PHU Jeznach Ltd., Poland. The soil, used for filling 5-litre pots and in field plots was characterized as podzolic.

To demonstrate the beneficial effect of applied fertilizers regardless of the climate and conditions of sorghum cultivation, the studies were performed in diverse weather conditions in Central Poland, where the plants were cultivated in $5 \mathrm{~L}$ pots and also in the north of the country in a field. In Central Poland, the temperature in July usually fluctuates from 8 to $32^{\circ} \mathrm{C}$, average annual precipitation is $528.3 \mathrm{~mm}$ and more frequent sunny days with drier air are noted than in North Poland where the average temperature ranges from 11 to $21^{\circ} \mathrm{C}$, precipitation reaches $655 \mathrm{~mm}$ and moist air from the nearby Baltic Sea is observed. All soil and plant treatments and their assessments were performed over the same time period.

The research was performed simultaneously in three experimental blocks, all in the two localities mentioned above and in 3 repetitions. In the second decade of April, the soil in each block was enriched with the synthetic fertilizer YaraMila Complex (YMC) at a dose of 0, 150 or $300 \mathrm{~kg} \mathrm{ha}^{-1}$, the latter one was recommended by the producer. Each block, was fertilized to a different extent with YMC, and consisted of 8 plots, each containing 10 plants grown separately in $5 \mathrm{~L}$ pots (pot experiment in Central Poland) or 6 plots with a size of $3 \times 3 \mathrm{~m}$ (field experiment in North Poland).

At the end of April, the soil in each subsequent plot within every block was fertilized as follows: 
A) pot experiment:

- ash from burnt Jerusalem artichoke (AT) at doses of 0 , $0.5,1,2,4 \mathrm{tha}^{-1}$

- ash $\left(4 \mathrm{t} \mathrm{ha}^{-1}\right)$ together with Apol-Humus (AH: $10 \mathrm{~L} \mathrm{ha}^{-1}$ ) and double leaf spraying with Stymjod 1.5\% (S: 5 L concentrate ha $\left.{ }^{-1}\right)$, at two-week intervals in July;

- ash $\left(4 \mathrm{tha}^{-1}\right)$ together with the waste from corn grain biodigestion to methane (E: $30 \mathrm{~m}^{3} \mathrm{ha}^{-1}$ );

- all 4 of the previously mentioned fertilizers (AT, AH, S,

E) used together.

B) field experiment:

- ash from burnt Jerusalem artichoke (AT) at doses of 0 , $1,2,4 \mathrm{tha}^{-1}$;

- ash (4 tha $\left.{ }^{-1}\right)$ together with Apol-Humus (AH: $10 \mathrm{~L} \mathrm{ha}^{-1}$ ) and double leaf spraying with Stymjod 1.5\% (S: 5 L concentrate ha $\left.{ }^{-1}\right)$, at two-week intervals in July;

- all 4 fertilizers (AT, AH, S, E) used together at the doses mentioned above.
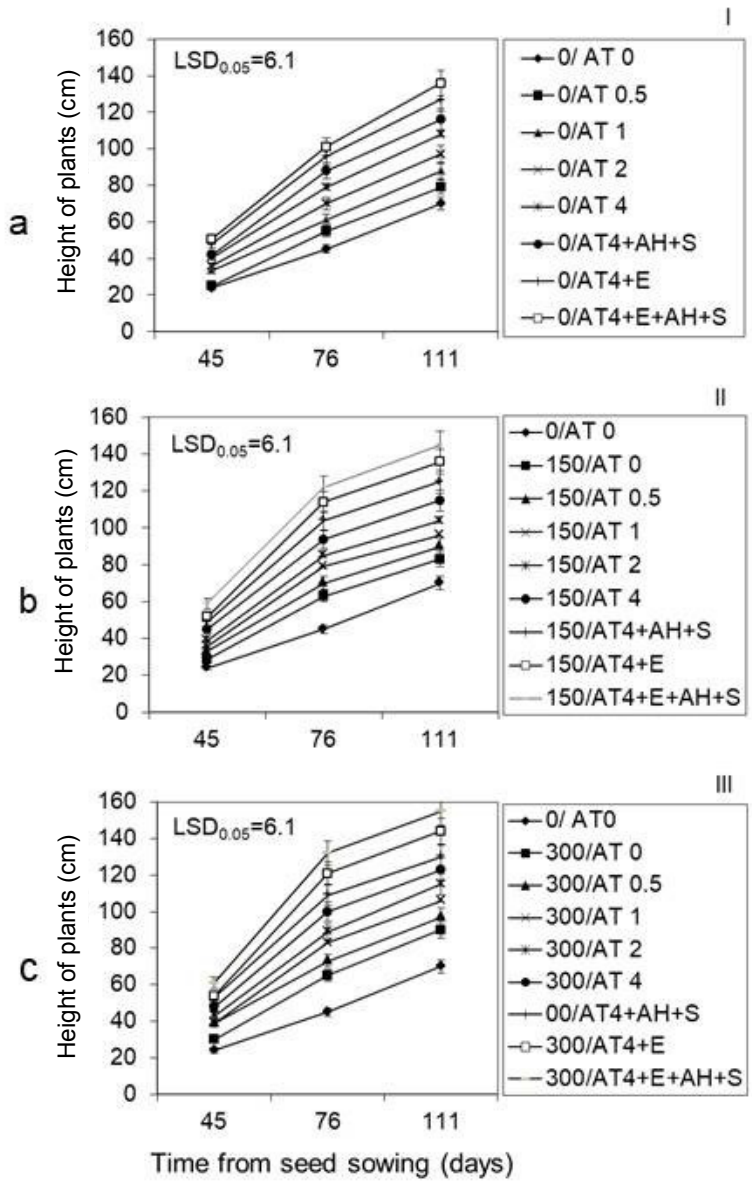

The YaraMila Complex, ash, Apol-Humus and the waste from a biogas plant, were mixed with the soil directly after their application. The plants were sprayed with Stymjod in the amount of $5 \mathrm{~L}$ of the commercial substance ha ${ }^{-1}$ at a concentration of $1 \%$. The configurations of all experimental variants are presented in Figs 1-3.

In the second decade of May, sorghum seeds were planted in the soil (enriched beforehand with YaraMila Complex, ash, waste and Apol-Humus), one seed in each pot, while in the field 175 seeds per plot in rows at a distance of $35 \mathrm{~cm}$ from each other and every $12 \mathrm{~cm}$ in a row, as recommended in practice. Each plant was grown in the field or set up in pots in the same area.

Plants were also grown on unfertilized plots and served as controls. The applied doses of waste, Apol-Humus and Stymjod were selected to be optimal based on previous tests carried out in the laboratory, pot tests and in the field (Romanowska-Duda et al., 2019a, 2019b).
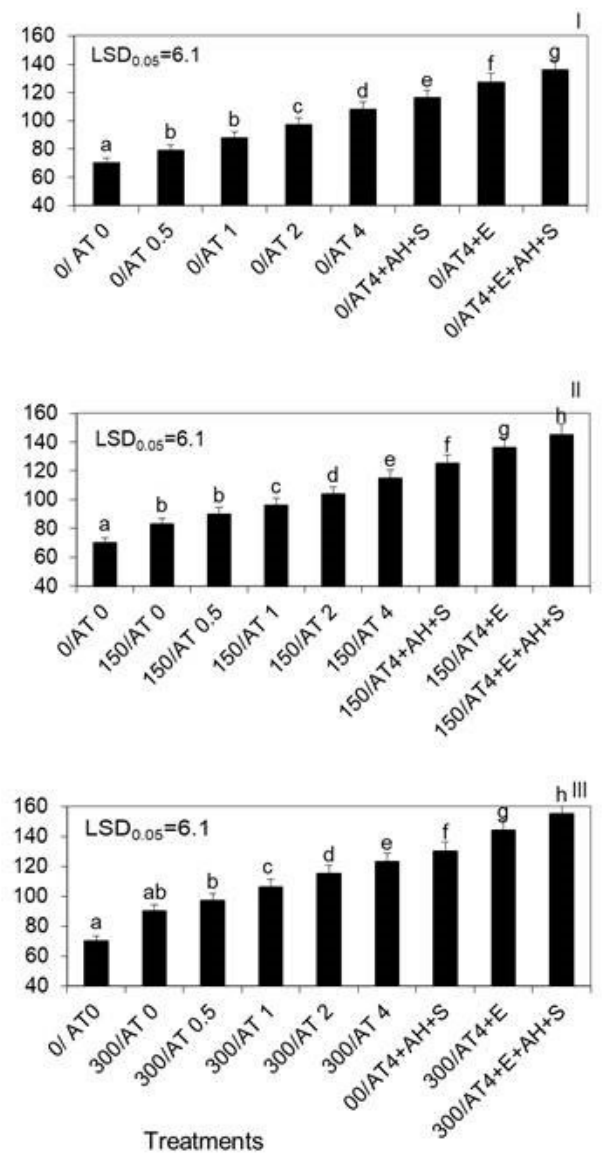

Fig. 1. Kinetics of growth and the final height of sorghum plants cultivated in pots, fertilized with YaraMila Complex at doses of: a - 0 (I), $\mathrm{b}-150$ (II) and $\mathrm{c}-300 \mathrm{~kg} \mathrm{ha}^{-1}$ (III) and as a part of each dose, with the ash from burnt Jerusalem artichoke biomass (AT $0-4.0 \mathrm{t}$ ha ${ }^{-1}$ ) used alone or supplemented with Apol-Humus (AH: $\left.10 \mathrm{~L} \mathrm{ha}^{-1}\right)$, Stymjod (S: $\left.5 \mathrm{~L} \mathrm{ha}^{-1}\right)$ and biogas plant waste $\left(\mathrm{E}: 30 \mathrm{~m}^{3}\right.$ ha $\left.{ }^{-1}\right)$. The LSD was calculated at a significance level of $\mathrm{p}=0.05$. 

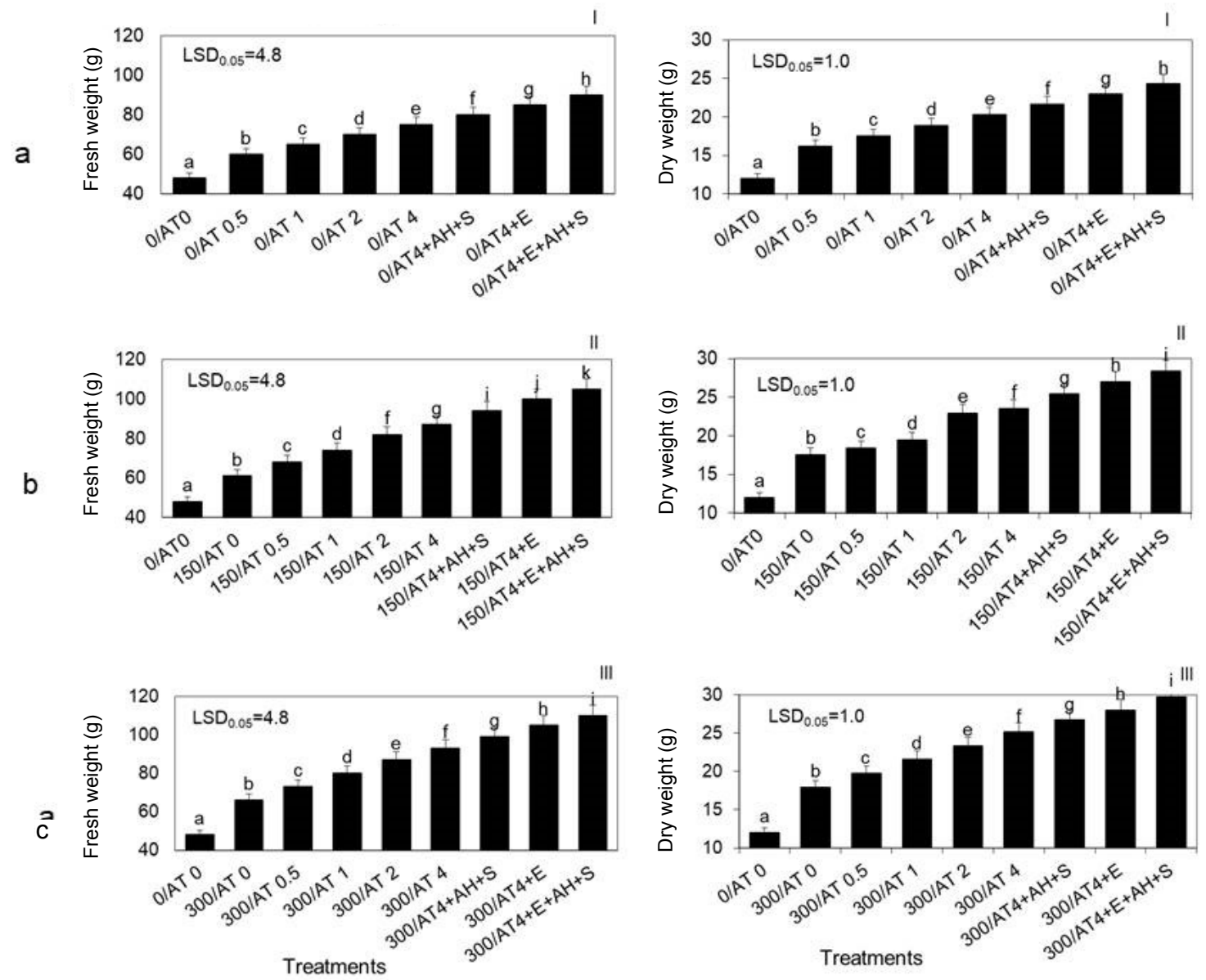

Fig. 2. Fresh and dry weight of one sorghum plants cultivated in pots, fertilized with YaraMila Complex at doses of: $a-0$ (I), b - 150 (II) and $\mathrm{c}-300 \mathrm{~kg} \mathrm{ha}^{-1}$ (III) and as a part of each dose, with the ash from burnt Jerusalem artichoke biomass (AT $0-4.0 \mathrm{tha}{ }^{-1}$ ) used alone or supplemented with Apol-Humus (AH: $10 \mathrm{~L} \mathrm{ha}^{-1}$ ), Stymjod (S: $5 \mathrm{~L} \mathrm{ha}^{-1}$ ) and biogas plant waste (E: $30 \mathrm{~m}^{3}$ ha ${ }^{-1}$ ). The LSD was calculated at a significance level of $\mathrm{p}=0.05$.

The effects of the studied fertilization treatments in pots and in field conditions were assessed by periodical height measurements of whole plants throughout the entire vegetative period, physiological activity was measured in July and biomass yield and its energy properties were assessed in the autumn. Assessments of plant physiological activity (gas exchange, chlorophyll content index, enzyme activity), the health of the plants and tests measuring the content of elements were carried out on fully developed leaves from as close as possible to the top of the plants. For each experimental variant and repetition, one leaf from each of 10 plants was removed for evaluation of quality in terms of health, gas exchange and enzyme activity. The measurements were carried out on separate leaves. In order to assess the element content, $100 \mathrm{~g}$ of leaves was taken from 10 plants and they were mixed together before analysis.
The leaves were collected in the third decade of July ( 2.5 months after seed sowing) at $25-30^{\circ} \mathrm{C}$, under conditions of sunshine and air humidity of $50-60 \%$.

The height of the plants was measured at monthly intervals throughout the whole growing season (Grzesik et al., 2017a).

The weight of the fresh green biomass and the dry one (dried at $130^{\circ} \mathrm{C}$ for 3 days) was assessed at the end of November on the basis of 5 plants taken from each experimental variant. The data presented in the figures were calculated for one plant to represent the average for the treatment (Grzesik et al., 2017a).

The assessment of gas exchange, was evaluated on the basis of net photosynthesis, transpiration, stomatal conductance and intercellular $\mathrm{CO}_{2}$ concentration measurements, these measurements were performed using 
a

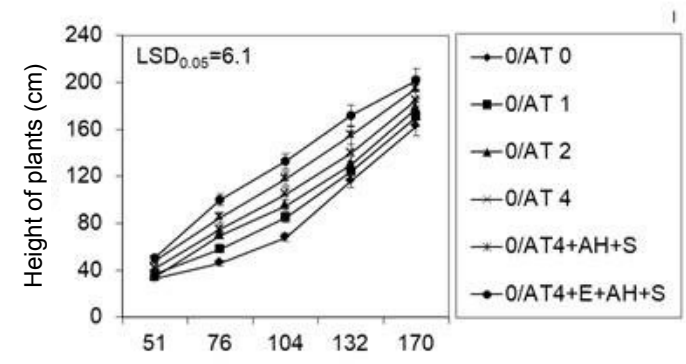

b

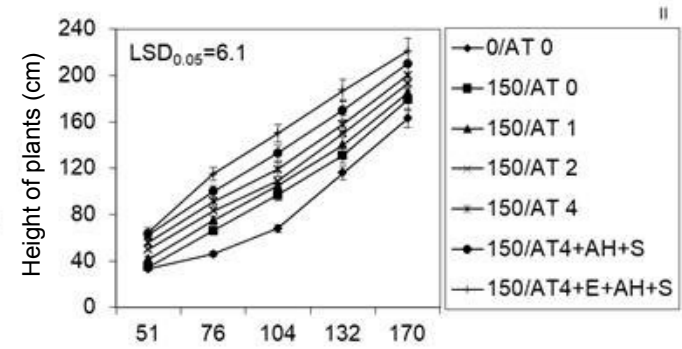

C

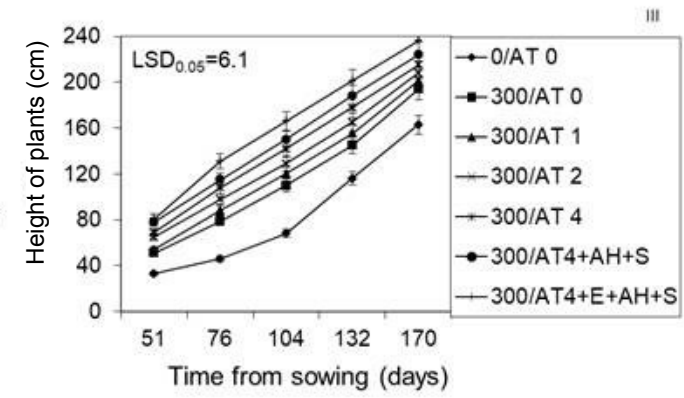

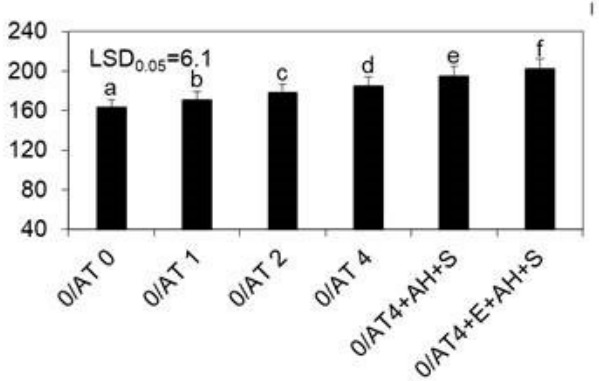
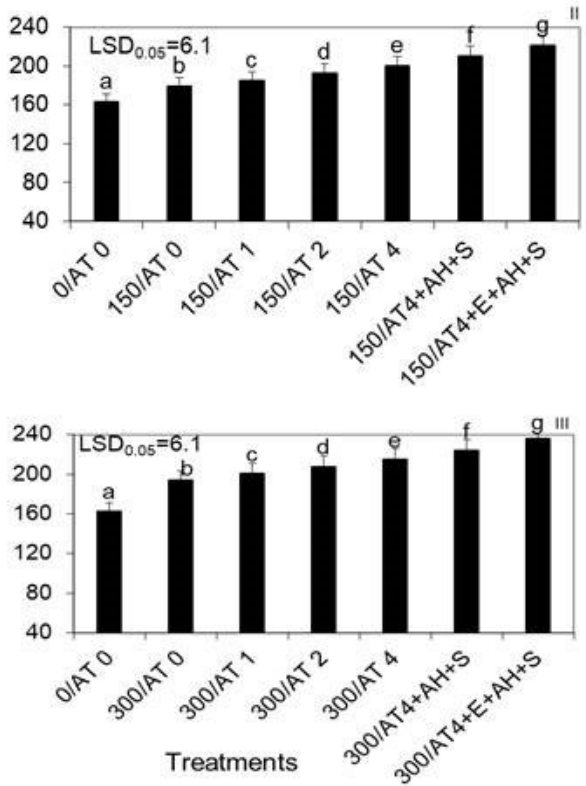

Fig. 3. Kinetics of growth and the final height of sorghum plants cultivated in a field, fertilized with YaraMila Complex at doses of: a -0 (I), $\mathrm{b}-150$ (II) and $\mathrm{c}-300 \mathrm{~kg} \mathrm{ha}^{-1}$ (III) and as a part of each dose, with the ash from burnt Jerusalem artichoke biomass (AT $\left.0-4.0 \mathrm{t} \mathrm{ha}{ }^{-1}\right)$ used alone or supplemented with Apol-Humus (AH: $\left.10 \mathrm{~L} \mathrm{ha}^{-1}\right)$, Stymjod (S: $\left.5 \mathrm{~L} \mathrm{ha}^{-1}\right)$ and biogas plant waste (E: $30 \mathrm{~m}^{3}$ ha $\left.{ }^{-1}\right)$. The LSD was calculated at a significance level of $p=0.05$.

TPS-2 - Portable Photosynthesis System (PP Systems, USA) (Grzesik et al., 2017a, 2017b; Romanowska-Duda et al., 2019a).

An index of chlorophyll content, in leaves which were not infected with pathogenic fungi, was estimated using an SPAD-502 chlorophyll meter (Konica Minolta, Japan) (Grzesik et al., 2017a).

The activities of the acid (pH 6) (EC 3.1.3.2) and alkaline $\left(\mathrm{pH}\right.$ 7.5) (EC 3.1.3.1) phosphorylases $\left(\mathrm{U} \mathrm{g}^{-1}(\mathrm{FM})\right.$ $\left.\mathrm{min}^{-1}\right)$ in leaves and RNase (EC 3.1.27.5) $\left(\mathrm{U} \mathrm{g}^{-1}(\mathrm{FM}) \mathrm{min}^{-1}\right)$ were studied using procedures demonstrated by Knypl and Kabzinska (1977).

The activity of dehydrogenases (EC 1.1.1.-) was measured with a technique presented by Górnik and Grzesik (2002) and Grzesik et al. (2017b). The spectrophotometer UVmini-1240 (Shimadzu, Japan) with a wavelength of $480 \mathrm{~nm}$ were used for formazan quantity assessment.
The element contents of the ash from burnt Jerusalem artichoke, Apol-Humus, Stymjod, and fully developed leaves from under a plant top and in podzolic soil, were measured before and after fertilization with the ash, the results were assessed using certified procedures in a licensed laboratory at the Research Institute of Horticulture in Skierniewice (Poland). The biomass of the leaves was concentrated through the evaporation of excess water and then mineralization took place in a microwave oven "Etho-1" (Milestone, Italy). Then, the composition and quantity of elements were studied in this concentrated biomass with the use of a plasma spectrometer (ICP), model DV2000 (Perkin-Elmer, USA). For assessment, different wavelengths which were characteristic of the examined elements were used. The total nitrogen content was studied using the Kjeldahl procedure following mineralization in concentrated $\mathrm{H}_{2} \mathrm{SO}_{4}$ with the addition of a catalyst. The nitrogen 
content was evaluated using a titration (Antweiler et al., 1996). Plant energy properties were estimated by a certified laboratory (Carbochem, Poland) using Polish procedures (Grzesik et al., 2017a).

The presented studies were carried out in three series (over subsequent years) in central (pot experiment) and northern Poland (field tests), and within each series, each experimental variant was studied using three replications (experimental plots). The experimental blocks, pot and field plots and replicates, with differently fertilized soil and plants, were situated randomly. The obtained data, presented as means from series and repetitions, were elaborated by applying an analysis of variance (ANOVA I), using Statistica 12. The means of the chosen parameters were displayed in Tables and grouped by employing the Newman-Keuls multiple range test. The statistical differences between the samples were presented at $\alpha=0.05$ significance level.

\section{RESULTS}

The ash from burnt Jerusalem artichoke contained significantly higher amounts of macro- and microelements than the podzolic soil used. The application of this ash resulted in increased quantities of nutrients in this soil (Table 1). The fertilizers used enhanced the quantity of nutrients in the soil and positively affected sorghum development, the changes depended on the method used. The improvements in growth, fresh and dry biomass yield and the physiological activity of the sorghum plants were closely related to increasing the doses of both fertilizers. Increasing the doses of the applied ash caused a proportional increase in the growth and physiological properties of sorghum, it was found that $4 \mathrm{tha}^{-1}$ was the most favourable concentration for plant development for each amount of YaraMila Complex. The positive influence of the YaraMila Complex and ash on plant development was heightened by the additional application of Apol-Humus $\left(10 \mathrm{~L} \mathrm{ha}^{-1}\right)$ or waste from a biogas plant $\left(30 \mathrm{~m}^{3} \mathrm{ha}^{-1}\right)$ added to the soil and boosted further, by plant spraying with Stymjod, 1.5\% (5 L concentrate ha $\left.{ }^{-1}\right)$. As a result, the greatest enhancement in sorghum growth was found after the application of YaraMila Complex $\left(300 \mathrm{~kg} \mathrm{ha}^{-1}\right)$, Jerusalem artichoke ash $\left(4 \mathrm{t} \mathrm{ha}^{-1}\right)$, waste from a biogas plant $\left(30 \mathrm{~m}^{3} \mathrm{ha}^{-1}\right)$, Apol-Humus $\left(10 \mathrm{~L} \mathrm{ha}^{-1}\right)$ and Stymjod $\left(5 \mathrm{~L} \mathrm{ha}^{-1}\right)$. When ash was applied at a dose of $4 \mathrm{tha}^{-1}$ together with lower amounts of YaraMila Complex $\left(0\right.$ or $\left.150 \mathrm{~kg} \mathrm{ha}^{-1}\right)$ it enhanced the growth kinetics and biomass yield to a slightly greater degree than a doubled dose of this artificial fertilizer used alone $(150$ or $300 \mathrm{~kg}$ $\mathrm{ha}^{-1}$, respectively). This means, that the application of ash together with a lower dose of synthetic fertilizer produces the same effect as twice the amount of this chemical fertilizer used alone (Figs 1-3).

The positive effect of the applied doses of YaraMila Complex or ash (supplemented or not supplemented with waste, Apol-Humus and Stymjod) on plant growth in pot trials were confirmed in field tests carried out in northern Poland under more favourable weather and soil conditions for growth than in the centre of the country. In that location, increasing the doses of fertilizers also proportionally improved plant development. However, sorghum plants cultivated in the field grew more intensively than those in

Table 1. Content of elements in the ash originating from Jerusalem artichoke burnt biomass and in the soil before and after fertilization with ash from Jerusalem artichoke $\left(4 \mathrm{t} \mathrm{ha}^{-1}\right)$, the non-centrifuged waste from the biogas plant, Stymjod and Apol-Humus

\begin{tabular}{|c|c|c|c|c|c|c|c|c|c|c|c|}
\hline \multirow{2}{*}{$\begin{array}{l}\text { Assessed } \\
\text { material }\end{array}$} & \multirow{2}{*}{$\begin{array}{l}\mathrm{N} \\
(\%)\end{array}$} & $\mathrm{P}$ & $\mathrm{K}$ & $\mathrm{Ca}$ & $\mathrm{Mg}$ & $\mathrm{Fe}$ & $\mathrm{Mn}$ & $\mathrm{Cu}$ & $\mathrm{Zn}$ & B & \multirow{2}{*}{$\begin{array}{c}\text { Dry } \\
\text { mass } \\
(\%)\end{array}$} \\
\hline & & \multicolumn{9}{|c|}{ (mg kg ${ }^{-1}$ dry weight) } & \\
\hline $\begin{array}{l}\text { Ash from } \\
\text { Jerusalem } \\
\text { artichoke }\end{array}$ & $0.40 \mathrm{c}$ & $8469 \mathrm{c}$ & $155211 \mathrm{c}$ & $143813 \mathrm{c}$ & $11703 \mathrm{c}$ & $2462 \mathrm{c}$ & $169 \mathrm{c}$ & $25.3 \mathrm{c}$ & $849 \mathrm{c}$ & $269 \mathrm{~b}$ & $94.1 \mathrm{~b}$ \\
\hline $\begin{array}{l}\text { Soil not } \\
\text { fertilized }\end{array}$ & $1.05 \mathrm{a}$ & $951 \mathrm{a}$ & $3835 \mathrm{a}$ & $25951 \mathrm{a}$ & $1591 \mathrm{a}$ & $667 \mathrm{a}$ & $45.9 \mathrm{a}$ & $21.9 \mathrm{a}$ & $30.3 \mathrm{a}$ & $63.6 \mathrm{a}$ & $25.7 \mathrm{a}$ \\
\hline $\begin{array}{l}\text { Soil + Jerus. a. } \\
\text { ash }\end{array}$ & $1.09 \mathrm{~b}$ & $1069 \mathrm{~b}$ & $4939 \mathrm{~b}$ & $32887 \mathrm{~b}$ & $2555 \mathrm{~b}$ & $1007 \mathrm{~b}$ & $76.4 \mathrm{~b}$ & $24.8 \mathrm{~b}$ & $36.2 \mathrm{~b}$ & $65.8 \mathrm{a}$ & $26.0 \mathrm{a}$ \\
\hline $\operatorname{LSD}_{0.05}$ & 0.009 & 102.0 & 200.0 & 449.1 & 228.9 & 124 & 13.0 & 2.2 & 5.8 & 10.3 & 0.3 \\
\hline \multicolumn{12}{|c|}{$\left(\mathrm{mg} \mathrm{L}^{-1}\right)$} \\
\hline Waste & $2459 \mathrm{c}$ & $274 \mathrm{~b}$ & $998 \mathrm{~b}$ & $302 \mathrm{a}$ & $119 \mathrm{~b}$ & $9.1 \mathrm{a}$ & $0.326 \mathrm{a}$ & $0.177 \mathrm{a}$ & $0.979 \mathrm{a}$ & $3.367 \mathrm{~b}$ & $1.5 \mathrm{a}$ \\
\hline Stymjod & $1231 \mathrm{~b}$ & $6652 \mathrm{c}$ & $62720 \mathrm{c}$ & $943 \mathrm{c}$ & $11570 \mathrm{c}$ & $18.9 \mathrm{~b}$ & $886 \mathrm{c}$ & $682 \mathrm{c}$ & $1476 \mathrm{c}$ & $576 \mathrm{c}$ & - \\
\hline Apol-Humus & $\begin{array}{c}15.20 \\
\mathrm{a}\end{array}$ & $15.7 \mathrm{a}$ & $20.0 \mathrm{a}$ & $466 \mathrm{~b}$ & $71 \mathrm{a}$ & $142 \mathrm{c}$ & $5.98 \mathrm{~b}$ & $0.89 \mathrm{~b}$ & $2.42 \mathrm{~b}$ & $0.94 \mathrm{a}$ & - \\
\hline $\mathrm{LSD}_{0.05}$ & 1.1 & 1.1 & 1.0 & 1.3 & 1.4 & 1.1 & 0.1 & 0.05 & 0.2 & 0.2 & 0.3 \\
\hline
\end{tabular}

$\mathrm{pH}$ : ash 12.0, soil 5.1, non-centrifuged waste 7.6, Apol-Humus 12.0. The data marked with the same letters within a column are not significantly different, according to the Newman-Keuls multiple range test at an alpha level of 0.05 . 
pots in all experimental variants. Thus, the tests in the container area were completed 111 days after sowing, i.e. in September, because the limited amount of soil in the fivelitre pots did not create adequate conditions for the further growth of plants beyond $160 \mathrm{~cm}$. The unlimited amount of soil available for plants in the field allowed for the sorghum to be cultivated until November and it even reached $240 \mathrm{~cm}$ in height (Figs 1 and 3).

The dependence between the advantageous changes in the kinetics of plant growth, the yield of fresh and dry biomass and the doses of YaraMila Complex and ash from burnt Jerusalem artichoke in pot and field studies demonstrated above, was confirmed by the proportionally increased activity of gas exchange and the index of chlorophyll content in leaves. Increasing the doses of YaraMila Complex and ash, either used separately or combined with the waste, Apol-Humus and Stymjod, proportionally enhanced the index of chlorophyll content, net photosynthesis, transpiration, stomatal conductance and decreased intercellular $\mathrm{CO}_{2}$ concentration, inversely proportional to the three aforementioned parameters of gas exchange. The dependence between the increased doses of YaraMila Complex or ash and the activity of gas exchange and index of chlorophyll content was comparable to that established between both fertilizer amounts and plant growth or biomass yield. The ash and biopreparations applied together with lower doses of YaraMila Complex ( 0 or $150 \mathrm{~kg} \mathrm{ha}^{-1}$ ) enhanced the gas exchange and the index of chlorophyll content to a slightly greater extent than this synthetic fertilizer used separately in a higher amount of 150 or $300 \mathrm{~kg}$ ha $^{-1}$, respectively (Figs 1-3, Table 2).

The increased doses of YaraMila Complex and of the studied ash applied alone or supplemented with the waste and both biopreparations also proportionally enhanced the activity of acid and alkaline phosphorylases, RNase, and dehydrogenases, to a similar extent in plants grown in pots and in a field. The activity of these enzymes was enhanced in all experimental variants and this was closely related to the increasing doses of YaraMila Complex and ash. Here also the ash dose of $4 \mathrm{tha}^{-1}$ was most favourable for enzyme activity for each synthetic fertilizer dose used. As mentioned above, the applied ash together with the lower doses of YaraMila Complex ( 0 or $150 \mathrm{~kg} \mathrm{ha}^{-1}$ ) also resulted in a slightly increased enzyme activity than when this artificial fertilizer was used alone and in a greater amount of 150 or $300 \mathrm{~kg} \mathrm{ha}^{-1}$, respectively. This indicates that gas exchange and enzymatic activity were similar under the influence of ash used at a lower dose of YMC or after the application of this synthetic fertilizer alone, but at twice the previous dose (Table 3).

The application of higher doses of the synthetic YaraMila Complex slightly increased the contents of N, $\mathrm{P}$ and $\mathrm{Mg}$ in leaves. The application of ash from burnt Jerusalem artichoke did not significantly change the content of macro elements in the leaves, except of for $\mathrm{K}$
(Table 4). However, the leaves fertilized with these bio fertilizers were greener and of a higher quality compared to the control. Correspondingly, the enrichment of podzolic soil with the studied ash and artificial fertilizer slightly increased the heat of combustion in the analytical state and calorific value in the working state and decreased the ash content in plants proportionally to the applied doses (Table 5).

\section{DISCUSSION}

Increasing the amount of plant biomass used in electricity production requires the development of new technologies for the sustainable cultivation of energy crops and a reduction in the use of synthetic fertilizers, whose fabrication and application in agriculture causes environmental pollution. The presented research is in line with these global trends and indicates that sorghum of the Rona 1 variety may be a well-growing and high-yield energy plant with good prospects for cultivation in Central Europe, and with multiple uses in the food and energy industries. Plants of this variety grow in Poland better than other cultivars cultivated in a warm climate (Office of the Gene Technology Regulator, 2017). They may be grown for silage or energy, which can be obtained by shoot burning or by their digestion to methane. Under Polish conditions, the average yield of sorghum green mass is $70 \mathrm{t} \mathrm{ha}^{-1}$ and $115 \mathrm{Nm}^{3}$ of biogas from 1 ton of shoots. It can be cultured on poor soils belonging to the IV and V quality class and under conditions of precipitation shortage. Thus in some years, it may be used as an alternative to maize, which produces $50 \mathrm{t} \mathrm{ha}^{-1}$ of green mass and requires more fertile and moist soil, which is difficult to guarantee in the changing climate of Central Europe (Krzystek et al., 2018). It is assumed that the results obtained may also be applied to the world production of sorghum as it is the fifth largest and most important cereal crop. This plant is an important dietary staple for more than 500 million people and a major livestock feed and raw material for biofuel and biogas (Almodares and Hadi, 2009; O'Hara et al., 2013). Sorghum is also a source of gluten-free food (O'Hara et al., 2013) and has the ability to adapt to drought, salinity and high temperatures, which occur due to rapid climate change which has become harmful to plant production (Mahmood et al., 2013; Office of the Gene Technology Regulator, 2017). The presented research indicates that the described ecological fertilization methods using Jerusalem artichoke ash are economical, environmentally friendly and can be used to increase the growth and yield of sorghum under different climate conditions as an alternative to artificial fertilization.

The presented studies were performed in different locations, in $5 \mathrm{~L}$ pots and in the field which allowed for the beneficial effect of the applied fertilizers to be assessed regardless of the climate and conditions of sorghum cultivation and to show the relationship between their doses and plant growth. The stimulating impact of 
Table 2. Gas exchange and index of chlorophyll content in sorghum plant as influenced by studied factors

\begin{tabular}{|c|c|c|c|c|c|c|}
\hline Applied waste & $\begin{array}{l}\text { YaraMila } \\
\text { Complex } \\
\left(\mathrm{kg} \mathrm{ha}^{-1}\right)\end{array}$ & $\begin{array}{c}\text { Net } \\
\text { photosynthesis } \\
\left(\mu \mathrm{m} \mathrm{CO}_{2} \mathrm{~m}^{-2} \mathrm{~s}^{-1}\right)\end{array}$ & $\begin{array}{c}\text { Transpiration } \\
\left(\mathrm{mmol} \mathrm{H}_{2} \mathrm{O} \mathrm{m}^{-2}\right. \\
\left.\mathrm{s}^{-1}\right)\end{array}$ & $\begin{array}{c}\text { Stomatal } \\
\text { conductance } \\
\left(\mathrm{mmol} \mathrm{m}^{-2} \mathrm{~s}^{-1}\right)\end{array}$ & $\begin{array}{c}\text { Intercellular } \\
\text { concentration of } \\
\mathrm{CO}_{2}\left(\mu \mathrm{mol} \mathrm{CO}_{2}\right. \\
\left.\text { airmol }{ }^{-1}\right)\end{array}$ & $\begin{array}{c}\text { Index } \\
\text { chlorophyll } \\
\text { content (SPAD) }\end{array}$ \\
\hline AT 0 & \multirow{8}{*}{0} & $4.0 \mathrm{a}$ & $0.61 \mathrm{a}$ & $164 \mathrm{a}$ & 3381 & $20.0 \mathrm{a}$ \\
\hline AT 0.5 & & $4.9 \mathrm{~b}$ & $0.72 b$ & $273 d$ & $326 \mathrm{k}$ & $20.5 \mathrm{~b}$ \\
\hline AT 1 & & $5.5 \mathrm{bc}$ & $0.77 b$ & $276 \mathrm{~d}$ & $315 \mathrm{j}$ & $21.4 \mathrm{~cd}$ \\
\hline AT 2 & & $6.5 \mathrm{e}$ & $0.89 \mathrm{~d}$ & 294 e & $304 \mathrm{i}$ & $22.2 \mathrm{fg}$ \\
\hline AT 4 & & 6.9 ef & $0.94 \mathrm{de}$ & $309 \mathrm{f}$ & $293 \mathrm{hi}$ & $22.8 \mathrm{hi}$ \\
\hline $\mathrm{AT} 4+\mathrm{AH} 10+\mathrm{S}$ & & $7.8 \mathrm{~h}$ & $0.99 \mathrm{e}$ & $319 \mathrm{~g}$ & $281 \mathrm{~g}$ & $23.3 \mathrm{j}$ \\
\hline AT $4+$ E 30 & & 8.4 hij & $1.09 \mathrm{f}$ & $328 \mathrm{~h}$ & $270 \mathrm{fg}$ & $23.7 \mathrm{kl}$ \\
\hline $\mathrm{AT} 4+\mathrm{E} 30+\mathrm{AH} 10+\mathrm{S}$ & & $9.2 \mathrm{kl}$ & $1.18 \mathrm{~g}$ & $360 \mathrm{i}$ & $235 \mathrm{e}$ & $23.9 \mathrm{~lm}$ \\
\hline AT 0 & \multirow{8}{*}{150} & $5.1 \mathrm{~b}$ & $0.72 \mathrm{~b}$ & $186 \mathrm{~b}$ & $316 \mathrm{j}$ & $20.5 \mathrm{~b}$ \\
\hline AT 0.5 & & $5.8 \mathrm{~cd}$ & $0.83 \mathrm{c}$ & $295 \mathrm{e}$ & $301 \mathrm{i}$ & $20.9 \mathrm{c}$ \\
\hline AT 1 & & $6.1 \mathrm{~d}$ & $1.29 \mathrm{~h}$ & $360 \mathrm{i}$ & $284 \mathrm{~h}$ & 21.9 ef \\
\hline AT 2 & & $7.5 \mathrm{fg}$ & $1.44 \mathrm{i}$ & $387 \mathrm{k}$ & $258 \mathrm{f}$ & $22.4 \mathrm{~h}$ \\
\hline AT 4 & & 8.1 ghi & $1.79 \mathrm{k}$ & 3991 & $235 \mathrm{e}$ & $23.1 \mathrm{ij}$ \\
\hline $\mathrm{AT} 4+\mathrm{AH} 10+\mathrm{S}$ & & $9.0 \mathrm{jk}$ & 1.931 & $419 \mathrm{~m}$ & $205 \mathrm{~d}$ & $23.9 \mathrm{~lm}$ \\
\hline AT $4+$ E 30 & & $9.2 \mathrm{kl}$ & $2.09 \mathrm{~m}$ & $425 n$ & $184 \mathrm{c}$ & $24.4 n$ \\
\hline $\mathrm{AT} 4+\mathrm{E} 30+\mathrm{AH} 10+\mathrm{S}$ & & $10.9 \mathrm{o}$ & $2.18 \mathrm{n}$ & 4360 & $161 \mathrm{~b}$ & 24.9 o \\
\hline AT 0 & \multirow{9}{*}{300} & $6.2 \mathrm{~d}$ & $0.83 \mathrm{c}$ & $234 \mathrm{c}$ & $287 \mathrm{~g}$ & $21.6 \mathrm{de}$ \\
\hline AT 0.5 & & $7.1 \mathrm{ef}$ & $0.94 \mathrm{de}$ & $298 \mathrm{f}$ & $265 \mathrm{f}$ & $22.0 \mathrm{f}$ \\
\hline AT 1 & & $7.6 \mathrm{~g}$ & $1.47 \mathrm{i}$ & $370 \mathrm{j}$ & $235 \mathrm{e}$ & $22.4 \mathrm{~h}$ \\
\hline AT 2 & & 8.1 ghi & $1.61 \mathrm{j}$ & 3991 & $226 \mathrm{e}$ & $23.0 \mathrm{ij}$ \\
\hline AT 4 & & $8.8 \mathrm{j}$ & 1.931 & $413 \mathrm{~m}$ & $196 \mathrm{~d}$ & $24.4 \mathrm{n}$ \\
\hline $\mathrm{AT} 4+\mathrm{AH} 10+\mathrm{S}$ & & $10.0 \mathrm{mn}$ & $2.08 \mathrm{~m}$ & 435 o & $184 \mathrm{c}$ & $24.9 \mathrm{o}$ \\
\hline AT4 +E 30 & & 10.5 no & $2.18 \mathrm{n}$ & $446 \mathrm{p}$ & $164 \mathrm{~b}$ & $25.5 \mathrm{p}$ \\
\hline $\mathrm{AT} 4+\mathrm{E} 30+\mathrm{AH} 10+\mathrm{S}$ & & $11.6 \mathrm{p}$ & $2.30 \mathrm{o}$ & $456 \mathrm{r}$ & $140 \mathrm{a}$ & $26.4 \mathrm{r}$ \\
\hline $\mathrm{LSD}_{0.05}$ & & 0.6 & 0.05 & 9.0 & 12.0 & 3.9 \\
\hline
\end{tabular}

The data marked with the same letters within a column are not significantly different, according to the Newman-Keuls multiple range test at an alpha level of 0.05 .

Jerusalem artichoke ash on sorghum development results from the fact that it is rich in macro- and microelements necessary for plant growth, this is similar to the findings of Meller and Bilenda (2012) and Uliasz-Bocheńczyk and Mokrzycki (2018) studying ash from some other agricultural plants. Increasing the doses of ash from burnt Jerusalem artichoke (from 0 up to $4 \mathrm{t} \mathrm{ha}^{-1}$ ) used separately or combined with synthetic YaraMila Complex (from 0 up to 150 and $300 \mathrm{~kg} \mathrm{ha}^{-1}$ ), the waste from a biogas plant, Apol-Humus and Stymjod enhanced the content of nutrients in the soil. These elements were absorbed by the plants and boosted plant kinetics, fresh and dry biomass yield, gas exchange, enzyme activity and the energy properties of the biomass produced, in proportion to the applied fertilizers doses. All doses of the applied ash, preferably $4 \mathrm{tha}^{-1}$, were shown to be favourable, regardless of the dose of the YaraMila Complex used together and in different climate conditions. This demonstrates that the applied ash may play a key role in the ecological improvement of soil fertility and may also increase plant tolerance to biotic and abiotic stress (Ramegowda and Senthil-Kumar, 2015). The results are in line with the studies of Puchalski et al. (2017), showing the stimulatory impact of ash from burnt conifers on the development of two varieties of Jerusalem artichoke. Stankowski et al. (2014) demonstrated the positive impact of ash from burnt plants, used alone or with compost, on 
Table 3. Activity of the selected enzymes in sorghum plant as influenced by studied factors

\begin{tabular}{|c|c|c|c|c|c|}
\hline Treatment & $\begin{array}{l}\text { YaraMila } \\
\text { Complex } \\
\left(\mathrm{kg} \mathrm{ha}^{-1}\right)\end{array}$ & $\begin{array}{l}\text { Phosphorylase } \\
\qquad(\mathrm{pH}=6.0) \\
\left(\mathrm{Ug} \mathrm{g}^{-1} \text { f.w. }\right)\end{array}$ & $\begin{array}{l}\text { Phosphorylase } \\
\qquad(\mathrm{pH}=7.5) \\
\left(\mathrm{Ug} \mathrm{g}^{-1} \text { f.w. }\right)\end{array}$ & $\begin{array}{c}\text { RNase } \\
\left(\mathrm{U} \mathrm{g}^{-1} \text { f.w. }\right)\end{array}$ & $\begin{array}{c}\text { Total dehydrogenases } \\
(\mathrm{mg} \text { formazan } \mathrm{x} \mathrm{g} \\
\left.\text { leaf }^{-1}\right)\end{array}$ \\
\hline AT 0 & \multirow{8}{*}{0} & $0.50 \mathrm{a}$ & $0.15 \mathrm{a}$ & $2.34 \mathrm{a}$ & $0.42 \mathrm{a}$ \\
\hline AT 0.5 & & $0.60 \mathrm{bc}$ & $0.23 \mathrm{~b}$ & $3.16 \mathrm{c}$ & $0.60 \mathrm{bc}$ \\
\hline AT 1 & & $0.64 \mathrm{de}$ & $0.25 \mathrm{c}$ & $3.24 \mathrm{~cd}$ & $0.64 \mathrm{~d}$ \\
\hline AT 2 & & $0.67 \mathrm{f}$ & $0.27 \mathrm{~d}$ & 3.40 ef & $0.68 \mathrm{e}$ \\
\hline AT 4 & & $0.74 \mathrm{gh}$ & $0.30 \mathrm{e}$ & $3.60 \mathrm{gh}$ & $0.74 \mathrm{f}$ \\
\hline $\mathrm{AT} 4+\mathrm{AH} 10+\mathrm{S}$ & & $0.77 \mathrm{ij}$ & $0.32 \mathrm{f}$ & $3.72 \mathrm{ij}$ & $0.77 \mathrm{gh}$ \\
\hline AT $4+$ E 30 & & $0.79 \mathrm{jk}$ & $0.34 \mathrm{~g}$ & $3.86 \mathrm{~lm}$ & $0.79 \mathrm{hi}$ \\
\hline $\mathrm{AT} 4+\mathrm{E} 30+\mathrm{AH} 10+\mathrm{S}$ & & $0.82 \mathrm{~lm}$ & $0.37 \mathrm{~h}$ & $3.94 \mathrm{~m}$ & $0.84 \mathrm{kl}$ \\
\hline AT 0 & \multirow{8}{*}{150} & $0.58 \mathrm{~b}$ & $0.22 \mathrm{~b}$ & $2.62 \mathrm{~b}$ & $0.58 \mathrm{~b}$ \\
\hline AT 0.5 & & $0.65 \mathrm{ef}$ & $0.27 \mathrm{~d}$ & $3.30 \mathrm{de}$ & $0.67 \mathrm{e}$ \\
\hline AT 1 & & $0.73 \mathrm{~g}$ & $0.30 \mathrm{e}$ & $3.50 \mathrm{fg}$ & $0.75 \mathrm{fg}$ \\
\hline AT 2 & & $0.74 \mathrm{gh}$ & $0.32 \mathrm{f}$ & $3.67 \mathrm{hij}$ & $0.79 \mathrm{hi}$ \\
\hline AT 4 & & $0.76 \mathrm{hi}$ & $0.34 \mathrm{~g}$ & $3.82 \mathrm{kl}$ & $0.81 \mathrm{ij}$ \\
\hline $\mathrm{AT} 4+\mathrm{AH} 10+\mathrm{S}$ & & $0.79 \mathrm{jk}$ & $0.36 \mathrm{~h}$ & $3.95 \mathrm{mn}$ & $0.84 \mathrm{kl}$ \\
\hline AT $4+$ E 30 & & $0.82 \mathrm{~lm}$ & $0.38 \mathrm{i}$ & 4.05 no & $0.86 \mathrm{~lm}$ \\
\hline $\mathrm{AT} 4+\mathrm{E} 30+\mathrm{AH} 10+\mathrm{S}$ & & $0.86 \mathrm{n}$ & $0.40 \mathrm{j}$ & $4.15 \mathrm{op}$ & $0.90 \mathrm{n}$ \\
\hline AT 0 & \multirow{9}{*}{300} & $0.62 \mathrm{~cd}$ & $0.26 \mathrm{~d}$ & $3.24 \mathrm{~cd}$ & $0.62 \mathrm{~cd}$ \\
\hline AT 0.5 & & $0.67 \mathrm{f}$ & $0.30 \mathrm{e}$ & $3.34 \mathrm{e}$ & $0.69 \mathrm{e}$ \\
\hline AT 1 & & $0.76 \mathrm{hi}$ & $0.32 \mathrm{f}$ & $3.65 \mathrm{hi}$ & $0.78 \mathrm{~h}$ \\
\hline AT 2 & & $0.79 \mathrm{jk}$ & $0.34 \mathrm{~g}$ & $3.77 \mathrm{jkl}$ & $0.82 \mathrm{jk}$ \\
\hline AT 4 & & $0.81 \mathrm{kl}$ & $0.36 \mathrm{~h}$ & $3.95 \mathrm{mn}$ & $0.85 \mathrm{~lm}$ \\
\hline $\mathrm{AT} 4+\mathrm{AH} 10+\mathrm{S}$ & & $0.83 \mathrm{~m}$ & $0.38 \mathrm{i}$ & $4.07 \mathrm{o}$ & $0.87 \mathrm{~m}$ \\
\hline AT $4+\mathrm{E} 30$ & & $0.86 n$ & $0.40 \mathrm{j}$ & $4.16 \mathrm{p}$ & 0.93 о \\
\hline $\mathrm{AT} 4+\mathrm{E} 30+\mathrm{AH} 10+\mathrm{S}$ & & $0.89 \mathrm{o}$ & $0.43 \mathrm{k}$ & $4.27 \mathrm{r}$ & $0.97 \mathrm{p}$ \\
\hline $\mathrm{LSD}_{0.05}$ & & 0.118 & 0.019 & 0.1 & 0.02 \\
\hline
\end{tabular}

The data marked with the same letters within a column are not significantly different, according to the Newman-Keuls multiple range test at an alpha level of 0.05 .

Table 4. Content of elements in the leaves of sorghum plant as influenced by studied factors

\begin{tabular}{|c|c|c|c|c|c|c|c|c|c|c|c|c|c|}
\hline \multirow{2}{*}{$\begin{array}{l}\text { YM } \\
\text { dose }\end{array}$} & \multirow{2}{*}{ Ash } & \multirow{2}{*}{$\begin{array}{l}\mathrm{N} \\
(\%)\end{array}$} & $\mathrm{P}$ & $\mathrm{K}$ & $\mathrm{Ca}$ & $\mathrm{Mg}$ & $\mathrm{Na}$ & $\mathrm{S}-\mathrm{SO}_{4}$ & $\mathrm{Fe}$ & Mn & $\mathrm{Cu}$ & $\mathrm{Zn}$ & $\mathrm{B}$ \\
\hline & & & \multicolumn{11}{|c|}{ (mg kg-1 d.w.) } \\
\hline 0 & 0 & $2.02 \mathrm{a}$ & $4786 \mathrm{a}$ & 20481 a & $7721 \mathrm{a}$ & $2590 \mathrm{a}$ & $127 \mathrm{a}$ & $1420 \mathrm{a}$ & $296 \mathrm{a}$ & $20.5 \mathrm{a}$ & $13.4 \mathrm{a}$ & $32.3 \mathrm{a}$ & $18.9 \mathrm{a}$ \\
\hline 0 & AT 4 & $2.03 \mathrm{a}$ & $4845 \mathrm{a}$ & $21557 \mathrm{~b}$ & 8154 a & $2625 \mathrm{ab}$ & $129 \mathrm{a}$ & $1430 \mathrm{a}$ & $300 \mathrm{a}$ & $20.6 \mathrm{a}$ & $13.5 \mathrm{a}$ & $32.4 \mathrm{a}$ & $19.1 \mathrm{a}$ \\
\hline 150 & AT 4 & $2.06 \mathrm{ab}$ & $4981 \mathrm{~b}$ & $21585 \mathrm{~b}$ & 8165 a & $2640 \mathrm{~b}$ & $131 \mathrm{a}$ & $1431 \mathrm{a}$ & $305 \mathrm{a}$ & $20.8 \mathrm{a}$ & $14.0 \mathrm{a}$ & $32.6 \mathrm{a}$ & $19.2 \mathrm{a}$ \\
\hline 300 & AT 4 & $2.12 \mathrm{~b}$ & $5019 \mathrm{~b}$ & $21620 \mathrm{~b}$ & 8180 a & $2653 \mathrm{~b}$ & $131 \mathrm{a}$ & $1434 \mathrm{a}$ & $307 \mathrm{a}$ & $21.0 \mathrm{a}$ & $14.1 \mathrm{a}$ & $33.0 \mathrm{a}$ & $19.2 \mathrm{a}$ \\
\hline $\operatorname{LSD}_{0.05}$ & & 0.05 & 60.2 & 201.6 & 488 & 36.2 & 5.1 & 6.3 & 12.4 & 1.0 & 0.7 & 0.9 & 0.4 \\
\hline
\end{tabular}

The data marked with the same letters within evaluated properties are not significantly different, according to the Newman-Keuls multiple range test at an alpha level of 0.05 . 
Table 5. Energy value properties of sorghum plant as influenced by studied factors

\begin{tabular}{|c|c|c|c|c|c|c|c|}
\hline \multirow{2}{*}{$\begin{array}{l}\text { Evaluated } \\
\text { properties }\end{array}$} & \multirow{2}{*}{ Research method } & \multirow{2}{*}{$\begin{array}{l}\text { Unit of } \\
\text { measure }\end{array}$} & \multirow{2}{*}{ Control } & \multicolumn{3}{|c|}{ YaraMila dose $\left(\mathrm{kg} \mathrm{ha}^{-1}\right)$} & \multirow{2}{*}{$\mathrm{LSD}_{0.03}$} \\
\hline & & & & 0 & 150 & 300 & \\
\hline \multicolumn{8}{|c|}{ Analytical state } \\
\hline $\begin{array}{l}\text { Analytical } \\
\text { humidity }\end{array}$ & PN-G-04511:1980 & $\%$ & $5.20 \mathrm{a}$ & $5.42 \mathrm{~b}$ & $5.73 \mathrm{c}$ & $6.39 \mathrm{~d}$ & 0.20 \\
\hline Ash & PN-ISO 1171:2002 & $\%$ & $10.09 \mathrm{~d}$ & $9.25 \mathrm{c}$ & $8.00 \mathrm{~b}$ & $7.47 \mathrm{a}$ & 0.50 \\
\hline $\begin{array}{l}\text { Heat of } \\
\text { combustion }\end{array}$ & PN ISO 1928:2002 & $\mathrm{kJ} \mathrm{kg}^{-1}$ & $16128 \mathrm{a}$ & $16357 \mathrm{~b}$ & $16914 \mathrm{c}$ & $17179 \mathrm{~d}$ & 210 \\
\hline \multicolumn{8}{|c|}{ Working state } \\
\hline $\begin{array}{l}\text { Transient } \\
\text { humidity }\end{array}$ & PN-G-04511:1980 & $\%$ & $50.92 \mathrm{a}$ & $50.84 \mathrm{a}$ & $50.15 \mathrm{a}$ & $49.45 \mathrm{a}$ & 0.68 \\
\hline Total humidity & PN-G-04511:1980 & $\%$ & $53.51 \mathrm{~b}$ & $53.40 \mathrm{~b}$ & $53.06 \mathrm{a}$ & $52.91 \mathrm{a}$ & 0.31 \\
\hline Ash & PN-ISO 1171:2002 & $\%$ & $4.99 \mathrm{~d}$ & $4.67 \mathrm{c}$ & $4.11 \mathrm{~b}$ & $3.87 \mathrm{a}$ & 0.20 \\
\hline Calorific value & PN ISO 1928:2002 & $\mathrm{kJ} \mathrm{kg}^{-1}$ & $6369 \mathrm{a}$ & $6419 \mathrm{~b}$ & $6566 \mathrm{c}$ & $6889 \mathrm{~d}$ & 18.10 \\
\hline
\end{tabular}

The data marked with the same letters within evaluated properties are not significantly different, according to the Newman-Keuls multiple range test at an alpha level of 0.05 .

wheat ear density and yields of grains, while Meller and Bilenda (2012) showed the positive impact of ash from straw, maize, energy willow and wood chips on miscanthus growth. Schiemenz and Eichler-Löbermann (2010) and Schiemenz et al. (2011) demonstrated the positive fertilizing effect of biomass ash and phosphorus on different crops. Jagodzinski et al. (2018) revealed the stimulatory influence of wood ash on Lemna minor growth, while Romanowska-Duda et al. (2019c) found a positive impact of ash from burnt sorghum on the growth and physiological properties of macrophytes. The cited studies, however, did not show the effectiveness of the interaction of ash and synthetic fertilizer used simultaneously, and the possibility of replacing a chemical fertilizer with ash from burned biomass in sorghum cultivation.

The application of ash from burnt Jerusalem artichoke as a biofertilizer, used separately or combined with the waste from biogas plants, Apol-Humus and Stymjod, made it possible to reduce by at least half the recommended amount of artificial fertilizers currently being used in sorghum cultivation and thus to lower the pollution of plants and the environment. Replacing synthetic fertilizers with easy-toobtain, economical biomass ash eliminates environmental contamination with dangerous substances and enables the production of organic food from sorghum, free of toxic impurities. Fewer toxic substances in consumed plants may promote the enhanced intake of various phytochemicals (tannins, phenolic acids, anthocyanin, phytosterols and policosanols) contained in sorghum by both humans and animals, although studies in this area have not been conducted here (Awika and Rooney, 2004). This is especially important when this plant is a basic component of human and animal diets (Almodares and Hadi, 2009; O'Hara et al., 2013). The possibility of reducing the recommended doses of synthetic fertilizers by $50 \%$ was also found after the foliar application of non-toxic cyanobacterial strains (Microcystis aeruginosa MKR 0105, Anabaena sp. PCC 7120 ) and Chlorella sp. in energy willow crop (Salix viminalis L.) (Grzesik et al., 2017a).

The noted changes and correlations concerning plant growth were also observed in all physiological activity assessments, regardless of the fact of whether the sorghum was grown for three subsequent years in the podzolic soil in pots or in a field and in different weather conditions of central and northern Poland. Although, due to a more favourable environment, weather conditions and the possibilities of unlimited space for root development in soil, the growth of plants was proportionally more intensive in the field than in $5 \mathrm{~L}$ pots, as was demonstrated in all experimental variants.

The obtained results indicate that the nutrients present in the applied ash from Jerusalem artichoke and YaraMila Complex positively affected the photochemical processes of photosynthesis in plants, which was also demonstrated by Kalaji et al. (2014) for corn and tomatoes. According to them, the activity of the photosynthetic system was associated with the content of the nutrients in plants. The elements in the studied ash and YaraMila Complex (N, K, P, Fe, Mg, $\mathrm{Mn}$ ) could increase the activity of several processes modulating the photosynthesis process, thereby causing a more intensive plant growth and biomass yield. For example, nitrogen affects the rate of photosynthesis, whereas potassium acts as an activator of enzymes involved in light phase reactions and participates in the process of regulating the transport of assimilates and stomata opening. Phosphorus deficiency adversely affects the phosphorylation process, 
while a deficit of iron reduces the intensity of photosynthesis and causes the chlorosis of leaves. Magnesium is present in chlorophyll and its deficiency decreases the content of this pigment, especially in older leaves. Manganese deficiency causes the perturbation of the membrane system in chloroplasts, which can lead to slower photosynthesis. As shown in the research presented, the applied ash from Jerusalem artichoke and YaraMila Complex contains these elements in amounts, which resulted in increased gas exchange and accelerated plant growth.

In the presented studies, the increased doses of ash and YaraMila Complex also caused a proportional increase in the chlorophyll content of leaves. The content of this dye is most commonly used as an indicator for $\mathrm{N}$ content, as demonstrated by Herrmann et al. (2010), Homolová et al. (2013) and Camino et al. (2018). According to Hamann et al. (2018) measuring the chlorophyll content and nitrogen balance can be a useful non-destructive method for assessing the physiological state of plants, as was found in young apple plants grown under water stress conditions. The problem is that the activity of the photosynthetic system may be reduced by an excessively low or high temperature and overly low humidity (Banks, 2018). The destructive effect of drought on photosynthetic activity can also be increased by other factors adverse to growth, which together can lead to damage to the oxidative system and photoinhibition (Goltsev et al., 2012).

Increasing the doses of ash from Jerusalem artichoke and YaraMila Complex enhanced the activity of acid and alkaline phosphorylases, RNase and dehydrogenase, proportionally to the amount of these fertilizers used. These enzymes play a crucial role in regulating plant development. The alkaline and acid phosphorylases regulate the distribution of phosphorus in plants, catalyse the hydrolysis of organic phosphorus and regulate the mineralization potential of organic phosphorus or soil biological activity (Dick and Tabatabai, 1992). RNase strengthens the defence mechanisms in plant tissues, as was observed in willow and corn plants under the influence of microalgae used as fertilizers, while dehydrogenases play a crucial role in respiration processes important for growth (Grzesik and Romanowska-Duda, 2015). The results obtained show that the ash from Jerusalem artichoke enhanced enzymatic activity, resulting in increased growth and the greater adaptation of sorghum plants to existing environmental conditions. A close correlation between several fertilization technologies, the abovementioned enzyme activities and the growth of plants was also demonstrated in corn and willow after the foliar application of microalgae (Grzesik and Romanowska-Duda, 2014, 2015; Grzesik et al., 2017a) and for particular energy crops fertilized with sewage sludge and waste from a biogas plant (Romanowska-Duda et al., 2010, 2019a).
The leaves fertilized with the tested biofertilizers were greener and of better quality compared to the control. Fertilizing plants with the YaraMila Complex in higher doses increased plant quality and slightly enhanced the contents of N, P and Mg in leaves, while the application of Jerusalem artichoke ash did not significantly increase the content of macro- and micronutrients in the leaves, except for potassium. This is related to the studies of Zapałowska et al. (2017) which demonstrated that fertilization with ash from coniferous trees did not increase the contents of $\mathrm{C}, \mathrm{N}$, $\mathrm{P}, \mathrm{S}, \mathrm{Ca}$ and $\mathrm{Mg}$ in Jerusalem artichoke shoots to any significant extent, $\mathrm{K}$ was an exception to this rule, the amount increased by $30 \%$. Similarly, the application of wood ash did not have a significant effect on the concentration of the measured elements in willow, although fertilization with this substance increased the size and quality of these plants (Park et al., 2005). This suggests that the nutrients present in the studied ash have the ability to increase the sorghum biomass yield and lead to processes which improve health and the quality of plants, a similar result was observed after the application of waste from corn grain biodegradation to methane (Romanowska-Duda et al., 2019a). The improved plant quality, health and colouration may be the result of the microelements increasing plant vigour and resistance to pathogen attack (Dimkpa et al., 2013; Dimkpa and Bindraban, 2016). They can also boost the synthesis of compounds that inhibit the growth of pathogens or enhance the biosynthesis of lignin and suberin in cell walls, which stiffens them and thus hinders the penetration of pathogens into tissues (Servin et al., 2015). The decreased occurrence of pests and placing a limitation on the adverse effect of diseases favours a higher plant quality and their adaptation to a changing climate (Ramegowda and Senthil-Kumar, 2015). The presented research shows the legitimacy of using Jerusalem artichoke ash, which limits synthetic fertilization and has a positive effect not only on sorghum growth but also on its quality, thereby decreasing the need for pesticide use. Moreover, healthier food can be produced from the better-quality sorghum treated with ash, as opposed to synthetic fertilizers containing toxic substances.

Sorghum plants fertilized with Jerusalem artichoke ash showed a slightly higher energy value, and also, its burnt biomass contained a little less ash. This indicates the benefits of using Jerusalem artichoke ash, which increases the yield of sorghum biomass and its usefulness for energy purposes. These findings are in line with the research of Kordas et al. (2012), and demonstrate that increasing the dose of mineral fertilization contributes to the enhancement of the energy value of plants. The connection found between the ash content and the energy properties of plants is in line with the studies of Reumerman and van den Berg (2018). They revealed that the content of this ash is negatively related to the calorific value of miscanthus. The slight modifications in these two parameters indicated that the quality of the sorghum was not changed significantly 
after the application of the studied ash and thus this plant may be used for the preparation of silage for animal nutrition and for energy purposes.

The research demonstrates that the effectiveness of Jerusalem artichoke ash fertilization, which was used together with reduced doses of synthetic YaraMila Complex, can be increased through the additional application of waste from biogas plants, Apol-Humus and Stymjod in all environmental conditions. The beneficial effect of fertilization with biogas plant waste on the growth and physiological activity of sorghum was demonstrated by RomanowskaDuda et al. (2019a). With regard to biopreparations, the stimulating effect on plant development may have been caused by chitosan polymers and humic acids contained in Apol-Humus as well as the nutrients, humic acids and iodine present in Stymjod. The positive effect of humic acids on plant development is well described in the literature (Calvo et al., 2014; Fahramand et al., 2014; Abdellatif et al., 2017). The beneficial effect of chitosan on the development and health of grape was revealed by Górnik et al. (2008) and on the growth of some other horticultural crops by Pichyangkura and Chandchawan (2015), Bistgani et al., 2017), Mukta et al. (2017), Muxika et al., (2017) and Kashyap et al. (2015). Plant growth stimulation by Stymjod may be caused by the macro- and microelements, humic acids and iodine contained in this biopreparation. Jeznach (2015) showed the positive effect of iodine, which is present in Stymjod, on cyto-morphological changes in cabbage and tomato. It increased xylem diameter and produced more frequent stomata opening, which probably resulted in enhanced nutrient uptake by plants and gas exchange. Iodine also increased the resistance of cabbage to stress and increased the content of several elements in it (Jeznach, 2015). According to Smoleń et al. (2011) iodine can increase the content of phosphorus, potassium and calcium and reduce the accumulation of iron in stored carrot roots. However, in the research of Krzepiłko et al. (2016), the biofortification of lettuce with iodine reduced the length of seedlings but did not affect their biomass and chlorophyll content. The seedlings contained more potassium and less sodium and manganese than the control. No significant differences in the contents of calcium, zinc, iron or copper were noted. Different results indicate the need for further research regarding the application of various forms of iodine to different plant species, taking into consideration the production methods of preparations which contain this element. The slightly different influence of iodine on plants could be caused by the formulation in which it was applied. Stymjod, containing iodine, is produced with nanotechnology in a patented device generating the phenomenon of cool plasma, in which a solution of specially selected mineral and organic compounds is subjected to cold synthesis (Jeznach, 2015). In most other studies, this element was applied alone.

The discovered possibility of using the ash from burnt Jerusalem artichoke as a fertilizer in sorghum crops may be useful in the present circular economy where the waste becomes a substrate in another production cycle. The results of the study show that the rapidly growing amount of biomass ash produced in the energy industry can be used in agriculture. The research indicated that the use of ash based fertilizer in sorghum under the changing climate conditions of central and northern Poland, not only allows for a reduction in the doses of synthetic fertilization contaminating the environment, but it also solves the serious problem of its storage which is expensive and dangerous for the surroundings. The effective fertilization of sorghum allows for the attainment of $8455 \mathrm{Nm}^{3}$ of biogas ha- ${ }^{-1}$ and the energy production of $200000 \mathrm{MJ} \mathrm{ha}^{-1}$ per year (Krzystek et al., 2018).

\section{CONCLUSIONS}

1. The sorghum Rona 1 variety is one of the promising and high yielding energy crops in Central Europe.

2. The fertilization of sorghum crops with the ash from burnt Jerusalem artichoke $\left(4 \mathrm{tha}^{-1}\right)$, separately or together with the waste from a biogas plant $\left(30 \mathrm{~m}^{3} \mathrm{ha}^{-1}\right)$, Apol-Humus $\left(10 \mathrm{~L} \mathrm{ha}^{-1}\right)$ and double leaf spraying with Stymjod $\left(5 \mathrm{~L} \mathrm{ha}^{-1}\right)$ greatly increased net photosynthesis, transpiration, stomatal conductance, the index of chlorophyll content, the activity of acid and alkaline phosphorylase, RNase and dehydrogenase, which markedly influenced the enhanced kinetics of plant growth, the yield of fresh and dry biomass and its energetic parameters.

3. The fertilization of sorghum crops with ash from burnt Jerusalem artichoke ( $\left.4 \mathrm{tha}^{-1}\right)$ may allow for the limitation of the recommended doses of chemical fertilizers by at least $50 \%$ and thus it may be an alternative to artificial fertilizers which are harmful to the environment.

4. The use of Jerusalem artichoke ash in sorghum crops solves the problem of the storage of this waste which is expensive and harmful to the environment.

5. The studied ash may be recommended as an economic biofertilizer in sorghum crops, if it is applied in proper amounts and in compliance with the national regulations.

Author contributions: ZRD carried out the experiment, processed the experimental data and wrote the portion of the research dealing with enzyme activity, MG conducted the research, processed the experimental data and wrote the portion of article concerning plant development and gas exchange. RJ assessed plant health. The authors read and approved the final manuscript.

\section{ACKNOWLEDGEMENTS}

The authors wish to thank Jolanta Zienkiewicz Expert-SITR Sp. z o.o. Poland for her participation in the performance of the field experiment and plant height measurement.

Conflicts of interest: The authors declare no conflict of interest. 


\section{REFERENCES}

Abdellatif I.M.Y., Abdel-Ati Y.Y., Abdel-Mageed Y.T., and Hassan M.A.M., 2017. Effect of humic acid on growth and productivity of tomato plants under heat stress. J. Hort. Res., 25(2), 59-66, https://doi.org/10.1515/johr-2017-0022

Almodares A. and Hadi M.R., 2009. Production of bioethanol from sweet sorghum: A review. African J. Agricultural Res., 4, 772-780, http://www.academicjournals.org/AJAR

Antweiler R.C., Patton C.J., and Taylor E., 1996. Automated colorimetric methods for determination nitrate plus nitrite, nitrite, ammonium and orthophosphate ions in natural water samples. U.S. Geological Survey, open-File Report 93-638, Denver, Colorado, 1-28.

Awika M.A. and Rooney L.W., 2004. Sorghum phytochemicals and their potential impact on human health. Phytochemistry, $65,1199-1221$, https://doi.org/10.1016/j.phytochem.2004.04.001

Banks J.M., 2018. Chlorophyll fluorescence as a tool to identify drought stress in Acer genotypes. Environ. Experim. Bot., $155,118-127$, https//doi.org/10.1016/j.envexpbot.2018.06.022

Biofuels in the EU, 2006. A vision for 2030 and beyond. Final draft of the Biofuels Research Advisory Council., ec. europa.eu/research/energy/pdf/draft_vision_report_en.pdf

Biofuels Progress Report, 2007. Report on the progress made in the use of biofuels and other renewable fuels in the Member States of the European Union, Communication from the Commission to the Council and the European Parliament, Commission of the European Communities, Brussels, 9.1.2007 COM 845 final. https://register.consilium.europa. eu/doc/srv?1=EN\&f=ST 53892007

Bistgani Z.E., Siadad S.A., Bakhshandeh A., Pirbalouti A.G., and Hashemi M., 2017. Interactive effect of draught stress and chitosan application on physiological characteristics and essential oil yield of Thymus daenensis Celak. Crop J., 5, 407-415, https://doi.org/10.1016/j.cj.2017.04.003

Buss W., Jansson S., and Masek O., 2019. Unexplored potential of novel biochar-ash composites for use as organo-mineral fertilizers. J. Clean Prod., 208, 960-967, https://doi. org/10.1016/j.jclepro.2018.10.189

Calvo P., Nelson L., and Kloepper J.W., 2014. Agricultural uses of plant biostimulants. Plant Soil, 383, 3-41, https://doi. org/10.1007/s11104-014-2131-8

Camino C., González-Dugo V., Hernández P., Sillero J.C., and Zarco-Tejada P.J., 2018. Improved nitrogen retrievals with airborne-derived fluorescence and plant traits quantified from VNIR-SWIR hyperspectral imagery in the context of precision agriculture. Int. J. Appl. Earth Obs. Geoinformation, 70, 105-117, https://doi.org/10.1016/j. jag.2018.04.013

Ciesielczuk T., Kusza G., and Nemś A., 2011. Fertilization with biomass ashes as a source of trace elements for soils. Ochrona Środowiska i Zasobów Naturalnych, 49, 219-227.

Dębowski M., Rusanowska P., Zieliński M., Dudek M., and Romanowska-Duda Z., 2018. Biomass production and nutrient removal by Chlorella vulgaris from anaerobic digestion effluents. Energies, 11, 1654, https://doi. org/10.3390/en11071654
Dick W.A. and Tabatabai M.A., 1992. Potential uses of soil enzymes, In: Soil Microbial Ecology (Ed. Jr., F.B. Metting), Applications in Agricultural and Environmental Management, Marcel Dekker, New York, 1992, 95-127.

Dimkpa C.O. and Bindraban P.S., 2016. Fortification of micronutrients for efficient agronomic production: a review. Agron. Sustain. Dev., 36, 7 , https://doi.org/10.1007/s13593-015-0346-6

Dimkpa C.O., McLean J.E., Britt D.W., and Anderson A.J., 2013. Antifungal activity of $\mathrm{ZnO}$ nanoparticles and their interactive effect with a bio-control bacterium on growth antagonism of the plant pathogen, Fusarium graminearum. BioMetals, 26, 913-924, https://doi.org/10.1007/s10534-013-9667

Faaij A.P.C., 2006. Bio-energy in Europe: changing technology choices. Energy Policy 34, 322-342, https://doi.org/10.1016/j.enpol.2004.03.026

Fang W., Delapp R.C., Kosson D.S., van der Sloot H., and Liu J., 2017. Release of heavy metals during long-term land application of sewage sludge compost: Percolation leaching test with repeated additions of compost. Chemosphere, 16, 271-280, https://doi.org/10.1016/j.chemosphere.2016.11.086

Fahramand M., Moradi H., Noori M., Sobhkhizi A., Adibian M., Abdollahi S., and Rigi K., 2014. Influence of humic acid on increase yield of plants and soil properties. Inter. J. Farming and Allied Sci., 3, 339-341, C2014 IJFAS Journal-2014-3-3/339-341/31 March, 2014.

Fernando A.L., Retteenmaier N., Soldatos P., and Panoutsou C., 2018. Sustainability of perennial crops production for bioenergy and bioproducts. In: Perennial grasses for bioenergy and bioproducts (Ed. E. Alexepoulou). Academic Press, Elsevier, 245-283, https://doi.org/10.1016/ B978-0-12-812900-5.00008-4

Goltsev V., Zaharieva I., Chernev P., Kouzmanova M., Kalaji H.M., Yordanov I., Krasteva V., Alexandrov V., Stefanov D., Allakhverdiev S.I., and Strasser R.J., 2012. Droughtinduced modifications of photosynthetic electron transport in intact leaves: analysis and use of neural networks as a tool for a rapid non-invasive estimation. Biochim. Biophys. Acta - Bioenerg., 1817, 1490-1498, https://doi. org/10.1016/j. bbabio.2012.04.018.

Górnik K. and Grzesik M., 2002. Effect of Asahi SL on China aster 'Aleksandra' seed yield, germination and some metabolic events. Acta Physiol. Plant., 24, 379-383, https://doi. org/10.1007/s11738-002-0033-5

Górnik K., Grzesik M., and Romanowska-Duda B.Z., 2008. The effect of chitosan on rooting of grapevine cuttings and on subsequent plant growth under drought and temperature stress. J. Fruit Ornam. Plant Res., 16, 333-343, www.inhort. pl/files/journal_pdf/journal_2008/full30 2008.pdf

Grzesik M. and Romanowska-Duda Z., 2014. Improvements in germination, growth, and metabolic activity of corn seedlings by grain conditioning and root application with cyanobacteria and microalgae. Pol. J. Environ. Stud., 23, 1147-1153, www.pjoes.com/pdf-89291-23149?filename= Improvements in.pdf

Grzesik M. and Romanowska-Duda Z.B., 2015. Ability of Cyanobacteria and green algae to improve of metabolic activity and development of willow plants. Pol. J. Environ. Stud., 24, 1003-1012, https://doi.org/10.15244/pjoes/34667 
Grzesik M., Romanowska-Duda Z., and Kalaji H.M., 2017 a. Effectiveness of cyanobacteria and green algae in enhancing the photosynthetic performance and growth of willow (Salix viminalis $\mathrm{L}$.) plants under limited synthetic fertilizers application. Photosynthetica, 55, 510-521, https://doi. org/10.1007/s11099-017-0716-1

Grzesik M., Górnik K., Janas R., Lewandowki M., Romanowska-Duda Z., and van Duijn B., 2017b. High efficiency stratification of apple cultivar Ligol seed dormancy by phytohormones, heat shock and pulsed radio frequency. J. Plant. Physiol., 21, 81-90, https://doi. org/10.1016/j.jplph.2017.09.007

Hamann F.A., Czaja S., Hunsche M., Noga G., and Fiebiga A., 2018. Monitoring physiological and biochemical responses of two apple cultivars to water supply regimes with nondestructive fluorescence sensors. Scientia Hort., 242, 51-61. https://doi.org/10.1016/j.scienta.2018.07.008

Herrmann I., Karnieli A., Bonfil D.J., Cohen Y., and Alchanatis V., 2010. SWIR-based spectral indices for assessing nitrogen content in potato fields. Int. J. Remote Sens., 31, 5127-5143, https://doi.org/10.1080/01431160903283892

Homolová L., Malenovský Z., Clevers J.G.P.W., GarcíaSantos G., and Schaepman M.E., 2013. Review of optical-based remote sensing for plant trait mapping. Ecol. Complex, 15, 1-16, https://doi.org/10.1016/j.ecocom.2013.06.003

Jagodzinski L.S., O'Donoghue M.T., Heffernan L.B., van Pelt F.N.A.M., O'Halloran J., and Jansen M.A.K., 2018. Wood ash residue causes a mixture of growth promotion and toxicity in Lemna minor. Sci. Total Environ., 625, 667676, https://doi.org/10.1016/j.scitotenv.2017.12.233

Jeznach A., 2015. General description of organic and mineral fertilizer "Stymjod" intended for foliar fertilization of plants. http://www.phu-jeznach.com.pl/doc/Stymjod/Opis_preparatu_STYMJOD_2.pdf

Kalaji H., Oukarroum A., Kouzmanova M., Brestic M., Zivcak M., Samborska I.A., Cetner M.D., Allakhverdiev S.I., and Goltsev V., 2014. Identification of nutrient deficiency in maize and tomato plants by in vivo chlorophyll a fluorescence measurements. Plant Physiol. Bioch., 81, 16-25, https:/www.sciencedirect.com/science/article/abs/ pii/S098194281400117X

Kashyap P.L., Xian X., and Heiden P., 2015. Chitosan nanoparticle based delivery system for sustainable agriculture. Internat. J. Biol. Macromol., 77, 36-51, https://doi. org/10.1016/j.ijbiomac.2015.02.039

Knypl J.S. and Kabzińska E., 1977. Growth, phosphatase and ribonuclease activity in phosphate deficient Spirodela oligorrhiza cultures. Biochem. Physiol. Pfl., 171, 279-287, https://doi.org/10.1016/S0015-3796(17)30311-6

Kordas L., Giemza-Mikoda M., and Jabłońska M., 2012. Evaluation of energy value of sorghum varieties depending on the time, sowing density and fertilization. Fragm. Agron., 29(3), 114-119, http://www.up.poznan.pl/pta/ pdf/2012/FA\%2029(3)\%202012\%20Kordas\%203.pdf

Krzepilko A., Zych-Wężyk I., Święciło A., Molas J., and Skwaryło-Bednarz B., 2016. Effect of iodine biofortifcation of lettuce seedlings on their mineral composition and biological quality. J. Elem., 21(4), 1071-1080, https://doi. org/10.5601/jelem.2015.20.4.1022
Krzystek L., Wajszczuk K., Pazera A., Matyka M., Slezak R., and Ledakowicz S., 2018. The influence of plant cultivation methods on biogas production: Energy efficiency. Proc. WasteEng2018 Conf., Prague, July 2-5, 710-720, https:// doi.org/10.1007/s12649-019-00668-Z

Mahmood A., Ullah H., Ijaz M., Javaid M.M., Shahzad A.N., and Honermeier B., 2013. Evaluation of sorghum hybrids for biomass and biogas production. Australian J. Crop Sci. 7(10), 1456-1462, www.cropj.com/mahmood_7_10_2013_1456_1462.pdf

Meller E., and Bilenda E., 2012. Effects of biomass ash on the physicochemical properties of light soil. Polityka energetyczna, 15(3), 287-292, Wyd. Instytutu GSMiE PAN Kraków, Poland.

Mukta J.A., Rahman M., Sabir A.A., Gupta D.R., Surovy M.Z., Rahman M., and Islam M.T., 2017. Chitosan and plant probiotic application enhance growth and yield of strawberry. Biocatal. Agric. Biotechnol., 11, 9-18, https:// doi.org/10.1016/j.bcab.2017.05.005

Muxika A., Etxabide A., Uranga J., Guerrero P., and de la Caba K., 2017. Chitosan as the bioactive polymer: Processing, properties and applications. Int. J. Biol. Macromol., 105, 1358-1368, https://doi.org/10.1016/j. ijbiomac.2017.07.087

Office of the Gene Technology Regulator, 2017. The Biology of Sorghum bicolor (L.) Moench subsp. bicolor (Sorghum). Australian Government Office of the Gene Technology Regulator, Version 1.1: July 2017.

O'Hara I., Kent G., Alberston P., Harrison M., Hobson P., McKenzie N., et al., 2013. Sweet sorghum: Opportunities for a new, renewable fuel and food industry in Australia. Report No: RIRDC Publication N. 13/087, RIRDC Project No. PRJ-005254, Rural Industries Research and Development Corporation. https://mafiadoc.com/finalreport-template-publications_59941add1723ddcf69a4 0a17.html

Park B.B., Yanai R.D., Sahm J.M., Lee D.K., and Abahamson L.P., 2005. Wood ash effects plant and soil in willow bioenergy plantation. Biomass Bioenerg., 28, 355-365, https:// doi.org/10.1016/j.biombioe.2004.09.001

Pichyangkura R. and Chandchawan S., 2015. Biostimulant activity of chitosan in horticulture. Sci. Hortic., 196, 49-65, https://doi.org/10.1016/j.scienta.2015.09.031

Piekarczyk M., Kobierski M., Kotwica K., and Szulc P.M., 2014. Effect of barley, wheat and rape straw ash on the manganese and iron content in sandy soil (in Polish). Ekologia i Technika, 22(1), 18-23.

Puchalski C., Zapalowska A., and Hury G., 2017. The impact of sewage sludge and biomass ash fertilization on the yield, including biometric features and physiological parameters of plants of two Jerusalem artichoke (Helianthus tuberosus L.) cultivars. Folia Pomer. Univ. Technol. Stetin Agric. Aliment. Pisc. Zootech., 332, 37-52, https://doi. org/10.21005/AAPZ2017.41.1.05

Pszczółkowska A., Pszczółkowski W., and Romanowska-Duda Z., 2019. Potential of Chlorella vulgaris culture for waste treatment from anaerobic biomass biodigestion at the Piaszczyna (Poland) integrated facility. J. Phycol., 55, 816829, https://doi.org/10.1111/jpy.12856 
Ramegowda V. and Senthil-Kumar M., 2015. The interactive effects of simultaneous biotic and abiotic stresses on plants: mechanistic understanding from drought and pathogen combination. J. Plant Physiol., 176, 47-54, https://doi. org/10.1016/j.jplph.2014.11.008

Reumerman P. and van den Berg D., 2018. Reduction of fouling, slagging and corrosion characteristics of Miscanthus. (The BIOMIS Project) Report. http://cordis.europa.eu/project/rcn/48287_en.html

Romanowska-Duda Z., Grzesik M., and Kalaji H.M., 2010. Phytotoxkit test in growth assessment of corn as an energy plant fertilized with sewage sludge. Environ. Prot. Eng., 36, 73-81.

Romanowska-Duda Z., Grzesik M., and Janas R., 2019a. Maximal efficiency of PSII as a marker of sorghum development fertilized with waste from a biomass biodigestion to methane. Front Plant Sci., 9, 1920, https://doi. org/10.3389/fpls.2018.01920

Romanowska-Duda Z., Janas R., and Grzesik M., 2019b. Application of Phytotoxkit in the quick assessment of ashes suitability as fertilizers in sorghum crops. Int. Agrophys., 33, 145-152, https://doi.org/10.31545/intagr/104597

Romanowska-Duda Z., Piotrowski K., Wolska B., Dębowski M., Zieliński M., Dziugan P., and Szufa S., 2019c. Stimulating effect of ash from Sorghum on the growth of Lemnaceae - a new source of energy biomass. In: Renewable Energy Sources: Engineering, Technology, Innovation (Eds M. Wróbel, M. Jewiarz, A. Szlęk). Springer Proceedings in Energy. Springer, Cham. https://doi.org/10.1007/978-3-030-13888-2_34

Santalla M., Omil B., Rodrigues-Soalleiro R., and Merino A., 2011. Effectiveness of wood ash containing charcoal as a fertilizer for a forest plantation in a temperate region. Plant Soil, 346, 63-78, https://doi.org/10.1007/s11104-011-0794-y

Schiemenz K. and Eichler-Löbermann B., 2010. Biomass ashes and their phosphorus fertilizing effect on different crops. Nutr. Cycl. Agroecosys., 87, 471-482, https://doi.org/10.1007/s10705-010-9353-9
Schiemenz K., Kern J., Paulsen H.M., Bachmann S., and Eichler-Lobermann B., 2011. Phosphorus fertilizing effects of biomass ashes. In: Insam H., Knapp B.A. (Eds.) Recycling of biomass ashes. Springer, Berlin, Heidelberg. 17-31, https://doi.org/10.1007/978-3-642-19354-5_2

Servin A., Elmer W., Mukherjee A., De La Torre-Roche R., Hamdi H., White J.C., Bindraban P.S., and Dimkpa C., 2015. A review of the use of engineered nanomaterials to suppress plant disease and enhance crop yield. J. Nanopart. Res., 17:92, https://doi.org/10.1007/s11051-015-2907-7

Smoleń S., Sady W., Rożek S., Ledwożyw-Smoleń I., and Strzetelski P., 2011. Preliminary evaluation of the influence of iodine and nitro gen fertilization on the effectiveness of iodine biofortification and mineral composition of carrot storage roots. J. Elementol., 16, 275-285, https://doi. org/101560/jelem.2011.16.2.11

Stankowski S., Hury G., Gibczyńska M., and Jurgiel-Małecka G., 2014. Impact of lime, biomass ash and compost as well as preparation of EM applications on grain yield and yield components of wheat. Inżynieria Ekologiczna, 38, 17-25, https://doi.org/10.12912/2081139X.29

Vassiliev S.V., Baxter D., Andersen L.K., and Vassileva C.G., 2013. An overview of the composition and application of biomass ash. Fuel, 105, 19-39, https://doi.org/10.1016/j. fuel.2012.10.001

Uliasz-Bocheńczyk A. and Mokrzycki E., 2018. The elemental composition of biomass ashes as a preliminary assessment of the recovery potential. Mineral Resources Managem., 34(4), 115-132, https://doi.org/10.24425/122593

Zapałowska A., Puchalski C., Hury G., and Makarewicz A., 2017. Influence of fertilization with the use of biomass ash and sewage sludge on the chemical composition of Jerusalem artichoke used for energy-related purposes. J. Ecol. Engineer., 18(5), 235-245, https://doi.org/ 10.12911/22998993/76214 